\title{
Function Code
}

National Cancer Institute

\section{Source}

National Cancer Institute. Function Code. NCI Thesaurus. Code C93570.

A coded value specifying the normal action performed by a structure or device. 